\title{
A SWORD IN A MADMAN'S HAND: PROFESSIONAL OPPOSITION TO POPULAR CONSUMPTION IN THE WATERS LITERATURE OF SOUTHERN ENGLAND AND THE MIDLANDS, $1570-1870$
}

\section{David Harley}

Although the major spas have received attention for their role in the development of resort towns, especially in the period before the invention of the seaside resorts, and the medical literature has been examined by historians of chemical analysis, spas have yet to be fully integrated into medical history. The legacy of medical antiquarianism may be partly responsible for this omission or perhaps historians regard the subject as well-known and unproblematic. Nevertheless, it is a little startling to read general histories of medicine in this period that mention medical waters only in passing, if at all. Spas in this period were scattered throughout most of the country, they were used by large numbers of both sick and healthy people, and the books that discussed their use were among the most widely read of all medical texts. Spa literature is part of medical literature as a whole, and displays many of the same preoccupations as other types of medical writing intended mainly for a lay audience.

When English physicians first publicized the benefits of drinking water or bathing in it, they followed European examples and attempted to integrate water into a Galenic scheme. The pioneering work of John Jones on Bath, after listing diseases, endeavoured "to shew the causes of the paynes before declared, that you may the reedyer cōsult, with your Phisicions thereof, as of all other things hereafter to bee mencioned, before ye seeke the ayde, of the Bathes ...". To this end, Jones included large diagrams showing the pervasive importance of the naturals and the nonnaturals in securing good health. Jones did not provide graphic accounts of the perils of unsupervised bathing but when he wrote of the waters of Buxton, located rather closer than Bath to his own Midlands practice, he asserted that they acted "more sweetly, more delicatly, more finely, more daintly, and more temperatly: not bringing halfe so many grievouse accidentes as Bath doth, yit lesse speedly ...".2

The secularization of holy wells is less prominent, as a subject, in southern than in northern authors, although it is undoubtedly present as a sub-text. If Thomas Hobbes

David Harley, c/o University of Oxford, Wellcome Unit for the History of Medicine, 45-47 Banbury Road, Oxford OX2 6PE.

\footnotetext{
1 John Jones, The Bathes of Bathes Ayde, London, 1572, ff. 6v.-7r.

${ }^{2}$ Idem, The benefit of the auncient Bathes of Buckstones, London, 1572, f. 2 r.
} 


\section{A sword in a madman's hand}

is to be believed, Buxton continued to be regarded as sacred to St Ann during the early seventeenth century. ${ }^{3}$ Authors based at most of the southern and Midlands spas had no such tradition to combat and concern is more often voiced by those seeking to publicize minor medical waters. Walter Bailey, writing in 1587 about a Warwickshire water, combined a Galenic interest in expert control with a Protestant attack on vestiges of Popery:

I found great concurse of al sorts of people affected with sundry and dissident diseases, which all in one manner used these waters, both inwardly and outwardly, without counsell or any just consideration, carried away with opinion, as it seemed, that the faculties and vertues of them, were supernaturally giuen from God without any ordinarie means, and so the use of the same not to depend of any order or aduise of Physicke, but that it was sufficient by any means to use them. Much like unto the superstition of our forefathers ....

For Bailey, as for all Protestant physicians, the use of waters fell firmly within the professional rather than the priestly sphere of competence because "in these our latter daies, God for the most part doth in his actions put natural meanes as instruments, of which the Philosophers do consider as natural and inferior causes". 4

Although the early writers, stressing God's providence in supplying the water that they recommended, rarely suggested that their own spa was actually dangerous, they had little hesitation in suggesting that other waters could be lethal. Tobias Venner, who practised in Bath during the spring and autumn, warned in noticeably unspecific terms against the Bristol waters, since the "divers symptomes or perillous accidents . . . cannot be well rectified or prevented without the presence of a Physician". 5 His insistence on the need for proper professional control of the use of water is characteristic of Galenic attitudes towards new active substances, also found in his writing on tobacco, and was not confined to English writers, having been foreshadowed in the works of the Scottish physician, William Barclay, on both tobacco and an Aberdeen spa. ${ }^{6}$

The abiding theme of the spa literature, prior to the challenge of chemical analysis, is the need for the physician alone to be the judge of the proper manner of bathing or drinking since he alone could consider the "many cautions and observations in the bathing, drawn from the particular constitutions of bodies; from the complication of diseases, and from many other circumstances which cannot be comprehended in general rules, or applyed to all bodies alike". Such was the excuse offered by Edward Jorden for omitting "many things about the virtues and uses of our Baths, which belong properly to the Physician, and cannot well be intimated to the patient without

\footnotetext{
${ }^{3}$ David Harley, 'Religious and professional interests in northern spa literature, 1625-1775', Bull. Soc. soc. Hist. Med., Dec. 1984, 35: 14-16; Thomas Hobbes, De mirabilibus pecci, [1636], sig. Blv.

${ }^{4}$ Walter Bailey, A briefe discours of certain bathes or medicinall waters in the Countie of Warwicke neere unto a village called Newnam Regis, 1587, sig. A3v, pp. 5-6.

5 Tobias Venner, The Baths of Bathe, London, 1637, p. 342.

${ }^{6}$ Idem, A briefe and accurate treatise, concerning, the taking of the fumes of tobacco, London, 1621; William Barclay, Nepenthes, or the vertues of tabacco, Edinburgh, 1614; idem, Callirhoe, the Nymph of Aberdene, rescusitat, Edinburgh, 1613.
} 


\section{David Harley}

dangerous mistaking". Jorden's was probably the most influential work on Bath in the seventeenth century, since Thomas Guidott re-issued it after the Restoration.

When Guidott came to write his own works on Bath, he was obliged to incorporate the findings of the chemists but this concession was seen as merely buttressing the position of learned physick, freeing waters from the imputation "of being accounted Empirical Medicines, whereas they are the exact composition of the best Physician, and perform their operations by virtue of the Ingredients they consist of and the blessing of God Almighty, as all other good Medicines and Prescriptions do".8 Indeed, the advent of chemical medicine made little impact on the advocacy of professional control, as may be seen from the work of Patrick Madan on Tunbridge Wells. He insisted that only the physician could weigh

all Indications, Contra-indications, and Co-indications according to Discretion . . . the Potation of Waters thus Circumstantiated, may deserve to be called the most powerful Hand of God; and keep their Reputation untainted: But without this Caution, they may prove a Sword in a Mad-Mans hand, and not at all Auxiliary, but pernicious and hurtful ....9

The cautions of physicians were clearly discerned as self-interested by contemporaries, especially those laymen who were enthusiastic about little-regarded waters. A clergyman who wrote in 1676 in favour of a Staffordshire water suggested that even physicians who privately used it criticized the spring in public: "It being indeed the Interest of the less Generous minded, both Physicians and Surgeons, to beat down the fame of Cures done by this Water, to inhance their own Advantage, though to the utter ruine of many Diseased Persons". ${ }^{10}$ There is an even greater degree of self-advertisement to be discerned in the waters literature than in most medical writing, since the authors were usually local specialists, although few were quite as explicit as John Peter, who publicized the Lewisham Wells in 1681: "it is necessary, that the learned and skilful Physician (especially such an One as is well acquainted with water) should be advised with, both before, at, and after the taking the water". He was pleased to note that "the disposing hand of Providence hath settled me in Lewisham, the place which God, out of his liberal bounty hath blest with this Medicinal water". 11

By the end of the century, the proliferation of spa literature enabled Benjamin Allen to write the first general survey of English medicinal waters, but he complained that too often the result of their use resembled "the ill Success that attends the empirical Use of the Cortex in Pthises and Feavers, without distinction of the Nature of the Symptom, and Propriety of the Medicine". He also noted the influence of popular convenience and medical fashions on the rise and fall of medicinal waters. ${ }^{12}$

\footnotetext{
${ }^{7}$ Edward Jorden, A discourse of natural bathes and mineral waters, 3rd ed., London, 1669, pp. $163,166$.

${ }^{8}$ Thomas Guidott, A discourse of Bathe, and the hot waters there, London, 1676, sig. B4v.

9 Patrick Madan, A phylosophical and medicinal essay of the Waters of Tunbridge, London, 1687, p.5.

${ }^{10}$ Samuel Gilbert, Fons sanitatis; or the Healing-Spring at Willow-bridge in Staffordshire, London, 1676, sig. A3v-A4r.

i1 John Peter, A treatise of Lewisham (but vulgarly called Dulwich) Wells in Kent, London, 1681, pp. 83, 87.

12 Benjamin Allen, The natural history of the chalybeat and purging waters of England, London, 1699, sig. Alr, p. 23.
} 


\section{A sword in a madman's hand}

This point was developed more fully by Robert Peirce:

Water-drinking in general hath been more used in this last Age, then it was in many before; and indeed Medicine, and Medicinal Processes, have been lyable to the Change of Fashions, as well as Cloaths; and Coaches, Meats and Drinks. There is scarce a County in England, that hath not now a Medicinal Water, that is not, at some Season of the Year, frequented; and some there are that have been formerly famous, and are now neglected, and scarcely any mention is made of them . . . .

The main anxiety of Peirce, a Fellow of the College of Physicians who lived in Bath, was the influence of the apothecaries there over patients' choice of therapy: they often employed no physician at all. The damage they did to themselves was to be blamed on the waters "no more than a Mad man's cutting his own Throat, is to be imputed to the Knife, or the Cutler that made it". ${ }^{13}$

Despite changes in the intellectual content of spa literature, the professional themes remained important until the mid-nineteenth century, as it attempted, vainly, to halt the flood of unsupervised water use. The terms employed by later writers were sometimes remarkably similar to those of the earlier, although adapted to more demure tastes. The chemical physician Dietrich Wessel Linden, writing on Llandrindod Wells in 1756, was appalled by the excessive consumption of the water which he was sure had damaged drinkers, although he admitted being ignorant of any examples.

For these Waters, under the Management of the Unskilful, are like edge-Tools, in some People's Hands; and this Resemblance, all good Medicines have with each other, that nothing is capable of doing a great deal of Good, but what may do Harm in Proportion.

He refused to speculate on such topics as accompanying medicine or the length of treatment, leaving such matters to the physician consulting on the case. ${ }^{14}$ Thomas Short, publicizing the Nevil-Holt water, provided a vast list of diseases for which it was useful and tacitly acknowledged unsupervised use, yet he insisted that in long-standing diseases "it's advisable to take the Opinion of a Physician who knows the Principles, Nature, and Properties of the Water, and how in their Case it is to be used". Although the pamphlet was anonymous, few readers could have been ignorant of the expert's identity since Short prescribed the water extensively, as he noted in his History of the air. ${ }^{15}$ In the mid-eighteenth century, such professionalism cut across political and religious divisions, uniting Whigs such as Linden with Tory moralists like Alexander Sutherland, who wrote on Bristol.

Medicinal-Waters have this in common, with other Medicines, that their good effects depend upon a proper Administration; and this requires a knowledge of the Patient, of the Distemper, and of the Waters. We need not wonder, that he, who is ignorant of either of these particulars, should miss his aim.

\footnotetext{
13 Robert Peirce, Bath memoirs, Bristol, 1697, pp. 250, 388-9.

14 Diederick Wessel Linden, A treatise on the three Medicinal Waters at Llandrindod, London, 1756, pp. 57, 116, 203.

15 [Thomas Short], The contents, virtues, and uses of Nevil-Holt Spaw-Water, 2nd ed., London, 1749, pp. 30-1; idem, A general chronological history of the air, vol. 2, London, 1749, pp. 260, 282.
} 


\section{David Harley}

All three authors combined an interest in chemical analysis, to varying degrees, with rational physick and a Hippocratic emphasis on "Temperance of every kind". ${ }^{16}$ As in the use of medicines before or with the waters, the proliferation of cautions ensured a role for the specialist physician. Writing on Bath in 1772, William Falconer provided some 25 pages of contra-indications. ${ }^{17}$

As the image of the knife indicates, there was a recognition that any powerful remedy must be regarded as potentially dangerous. Thomas Short, discussing Buxton, commented that "it may with Justice be objected, if these Waters are bad for nothing, they are good for nothing; we shall therefore give not only its Advantages, but Disadvantages". He warned that Buxton water "is not to be trifled with, for if it be unnecessarily used, it will certainly do Harm". ${ }^{18}$ This threat was sometimes even recognized by guidebooks, such as a 1771 account of Tunbridge Wells which declared that "Nothing can hurt the reputation of these chalybeate waters, except the crying them up, in the style of empirics as good for everything". ${ }^{19}$ Even authors like John Nott, who affirmed that Bristol water, unlike that of Knaresborough, was completely harmless and suited to self-administration, feared lest "its innocence lead us to consider it as inefficacious and nugatory". 20

Guidebooks, which were generally produced by those with a commercial interest in the prosperity of a spa, were rarely inclined to mention possible dangers. Thus Cheltenham guides emphasized the observation of Charles Lucas, that local people drank large quantities of the water without sustaining any injury. ${ }^{21}$ Such comments horrified the physicians who moved into the developing spa town, such as Thomas Jameson, who felt that imprudent advice was as dangerous as self-diagnosis. "It is not surprising that patients should deceive themselves, when the faculty propagate errors, and praise mineral waters indiscriminately."

It was perhaps relatively easy to portray the purging waters as medicinal since they had not only an obvious effect but also a distinctive taste. As Jameson remarked, "If they had no bad taste nor smell, the patients would have no confidence in their virtues ...". 22 The chalybeate waters required a greater insistence on the potential danger, as the Antwerp-born physician, Lewis Rouse, recognized in 1632.

Many haue falne into diseases, as feavers and agues, by comming vnadvisedly and vnprepared to those waters, although . . . there is nothing better for agues, then they are, if they be rightly and advisedly vsed, the body being first prepared and purged.

Rouse's cautions continued to be influential in Tunbridge Wells, being reproduced

\footnotetext{
${ }^{16}$ Alexander Sutherland, The nature and qualities of Bristol-Water, Bristol, 1758, pp. 99, 121-3.

17 William Falconer, An essay on the Bath Waters, London, 1772, vol. 1, pp. 366-72, vol. 2, pp. 90-9, 261-8.

${ }_{18}$ Thomas Short, The natural, experimental, and medicinal history of the Mineral Waters of Derbyshire, Lincolnshire and Yorkshire, London, 1734, p. 67.

19 A general account of Tunbridge Wells, London, 1771, p. 7.

20 John Nott, Of the Hotwell Waters near Bristol, Bristol, 1793, pp. 77, 86-7

${ }^{21}$ The Cheltenham guide, London, 1781, p. 45n; Simeon Moreau, A tour to Cheltenham Spa, Bath, 1783, p. 42 .

${ }^{22}$ Thomas Jameson, A treatise on Cheltenham Waters, and bilious diseases, Cheltenham, 1803, pp. xi-xiv, xxxviii-xxxix.
} 


\section{A sword in a madman's hand}

first in an exact reprint of 1671 and then, stripped of all references to Galen, in an edition of 1725 that purported to be a new work by a living author. ${ }^{23}$ Linden reported that the proprietor of Islington attributed its decline to "the ill Effects some had found by using it immoderately" but in his general remarks Linden recognized the real problem of such waters by solemnly warning the consumers "to assist their Constitution by a salutary Diet or Regimen, to expect patiently the After-Effects of the Mineral Waters that so frequently answer their Intention . . ."24 Although steel was always seen as advantageous in cases of debility, the robust were warned against it. The chemist Friedrich Christian Accum, writing on Thetford in 1819, passed on a local medical practitioner's account of a robust man who "fell down senseless in a state of apoplexy" after drinking the water for three days. ${ }^{25} \mathrm{Dr}$ Yeats of Tunbridge Wells went so far as to suggest that robust persons should not live in the area unless they could avoid the chalybeate water that was frequently used "for culinary purposes . . . which produces costiveness, congestion in the liver, and, ultimately, preternatural fulness in the brain, with its consequences". 26

Warm bathing was also a potent source of danger. Charles Lucas argued that it should be prescribed in the same way as medicine, in precise detail, since "without the strictest Observance of these Cautions, Mischiefs infinite must ensue". Included among the host of likely dangers were frenzy, fainting, and fevers, but he was referring to simple warm bathing. After quoting Lucas, William Baylies stressed the even greater care needed in the use of Bath waters, "to be considered as medicated Lotions, whose Effects on the Solids and Fluids in general, as well as on the Pores of the Skin in particular, must be remarkably different". ${ }^{27}$ William Henry Robertson, physician to the Buxton Bath Charity and author of the most widely read medical work on Buxton, warned that only the strong should bathe in the evening and great danger lay in bathing on successive days. Most importantly, "Persons in health should not either bathe repeatedly in these waters, or drink them". To discourage "tampering with these stimulating and powerful agents", he related the case of a healthy young woman who became comatose and died in 1839 as a result of bathing only once. ${ }^{28}$

Buxton was one of those former holy waters which gave particular difficulties to physicians since it was impossible "to discover any efficient chymical Properties", as George Pearson stated in his two-volume work on Buxton, published to coincide with the spa's redevelopment in 1784 by the Duke of Devonshire. It was necessary to attribute its healing power to "its Qualities as simple Water" and to the changes in all the other non-naturals experienced by visitors to the spa although, as Pearson candidly admitted, "any Thing whatever may, from the Nature of the human

\footnotetext{
${ }^{23}$ Lodwick Rowzee, The Queenes Welles, London, 1632, p. 61; idem, London, 1671, p. 61; Lewis Rouse, Tunbridge Wells: or, a directory for the drinking of those waters, London, 1725, p. 16.

${ }^{24} \mathrm{D}$. W. Linden, A treatise on the origin, nature, and virtues of chalybeat waters and natural hot baths, London, 1748, pp. 122, 278.

${ }^{25}$ Friedrich Christian Accum, Guide to the Chalybeate Spring of Thetford, London, 1819, pp. 116-17.

${ }^{26}$ G. D. Yeats, 'Some general remarks on the diseases observed at Tunbridge Wells ...', in John Britton, Descriptive sketches of Tunbridge Wells, London, 1833, p. 76.

27 William Baylies, Practical reflections on the uses and abuses of Bath Waters, London, 1757, pp. 225-9.

${ }^{28}$ William Henry Robertson, A guide to the use of Buxton Waters, 4th ed., London, 1847, pp. 16, 24, 26.
} 


\section{David Harley}

Passions, and from professional Motives, continue in Use, and that in Frequency, in Proportion to its Agreeableness and Conveniency of Application".29

Malvern was another such pure water, lacking even Buxton's unusual feature of flowing tepid from the ground. John Wall of Worcester attributed its healing power to its purity although he believed that it contained a spirit which quickly evaporated and which his son identified as fixed air. ${ }^{30}$ Other Worcester physicians could not find any fixed air but they agreed that the purity of the water and the advantages of the Malvern environment combined to cure in various ailments. ${ }^{31}$ Dr Philips Wilson in 1805 attempted to refute the popular opinion of purity but his analysis produced such minute quantities of minerals that some ingenuity was required to insist on their medicinal efficacy. ${ }^{32}$ Although lay publicists of Malvern did what they could with this disagreement, the general opinion prevailed. ${ }^{33}$

For medical writers of the early nineteenth century, it was no great surprise that waters such as Malvern, Buxton, and Bristol, which were no more chemical than common pump water, should perform cures. This could readily be attributed to such factors as change of air, exercise, relaxation, regular habits of life, and confidence in the remedy, as Jameson and Pearson pointed out. ${ }^{34}$ Public confidence, however, was not easily secured, especially once it was admitted that plain water and fresh air were the main ingredients of the treatment. There were too many potential candidates for any spa to be certain of remaining fashionable. In an ideal world, perhaps, scientific inquiry based on "accurate journals of the principal cases" would have determined the reputation of spas, as urged by Fothergill of Cheltenham. This would more fully inform the public.

It would also rescue our medicinal springs from the opprobrium of being frequented as they now commonly are, on no better foundation than that of fashion, or caprice. Some it would raise to public fame, that are now obscurely known; others it would strip of their false renown, by exposing the fabulous cures, attributed to them by ignorance, self-interest, or superstition. Each would thus, in time, find its own proper level in the scale of merit. Their natural and chemical history being finally completed, their comparative virtues would be ascertained, science enlightened, and the practice of medicine improved. ${ }^{35}$

In reality, however, medicine had to give way to the vagaries of lay fashion. Few spas

${ }^{29}$ George Pearson, Observations and experiments for investigating the chymical history of the Tepid Springs of Buxton, vol. 1, London, 1784.

${ }^{30}$ John Wall, Experiments and observations on the Malvern Waters, 2nd ed., Worcester, 1757, pp. 6, 13, 22-4; idem, Medical tracts, ed. Martin Wall, Oxford, 1780, p. 288.

31 J. Barrett, A description of Malvern, and its environs, 2nd ed., Worcester, 1803, pp. 34-5; John Chambers, A general history of Malvern, Worcester, 1817, pp. 115n, 143.

32 A. Philips Wilson, An analysis of the Malvern Waters, Worcester, 1805, pp. i-iv, 59-68.

33 Letters on Malvern, descriptive and historical, Worcester, n.d., pp. 15-21; Mary Southall, A description of Malvern, Malvern, 1882, pp. 14-19.

34 Jameson, op. cit., note 22 above, pp. xxxi-xxxix; Pearson, op. cit., note 29 above, pp. 18-19. The Galenic non-naturals did not disappear from health literature despite the desuetude of the collective description, mocked by Sterne and Coleridge.

${ }^{35}$ A. Fothergill, $A$ new experimental inquiry into the nature and qualities of the Cheltenham Water, Bath, 1785, pp. 69-70. 


\section{A sword in a madman's hand}

had the advantage of Leamington, the rapid expansion of which was attributed, by medical men, to the discovery of new and varied springs between 1784 and 1819 , the publication of scientific analysis, and the improvement of facilities and accommodation. Melksham Spa in Wiltshire flourished for less than a decade despite substantial speculative investments, being too close to Bath. Ilkeston Baths fell into disuse because they were too close to Buxton and Matlock. ${ }^{36}$

For small spas, such as Malvern and Matlock, the rise of hydrotherapy came as a godsend. Wilson and Gully, who established the Priessnitz method at Malvern, developed a huge trade and threw back the accusation of danger at their medical critics, whom they suggested were motivated by mere self-interest. They endeavoured to convince the public that the water cure was only dangerous in the hands of amateurs, a position accepted by their devoted patients. ${ }^{37}$ As the hydropathist Ralph Barnes Grindrod noted, the difficulty of defining the medical properties of Malvern water had become an asset. By 1858, Malvern boasted five large hydropathic establishments, to which it owed its prosperity. ${ }^{38}$ Hydropathy was not the exclusive preserve of physicians - Grindrod's MD was awarded by Lambeth Palace-and it was increasingly associated with such fringe concerns as teetotalism and homeopathy. The attendance of medical men proved incompatible with the practice of hydropathy at Matlock, so unorthodox were the principles established by the Methodist philanthropist, John Smedley, whose patients clearly regarded the water cure in religious terms. ${ }^{39}$

The rise of amateur hydropathy, the greater emphasis on the air and exercise of the spa resort, and the development of resorts devoted increasingly to pleasure were all factors in the decline of the English spa. Perhaps most important of all was the increase in foreign travel. The professionals lost control and the spas eventually lost their medical endorsement, a process completed by the exclusion of spa medicine from the National Health Service. This was by no means an inevitable result-spa medicine continues to thrive in several European countries-but the mere assertion of professional control by the issuing of solemn warnings was insufficient to reverse the impact of social changes outside the realm of medical practice.

\footnotetext{
${ }^{36}$ Charles Loudon, A practical dissertation on the Waters of Leamington-Spa, Leamington Spa, 1828, pp. 6-12; Melksham Spa, Wiltshire: guide and directory, Melksham, 1963, p. 15; Edwin Trueman, History of Ilkeston, Ilkeston, 1880, p. 61.

37 James Wilson, 'Two letters to Dr. Hastings of Worcester' in The water cure, 2nd ed., London, 1843, p. 18; J. Wilson and James Gully, The dangers of the water cure ...., London, 1843, pp. 18-20; Richard J. Lane, Life at the water cure, or a month at Malvern, London, 1846, pp. xv-xvi.

${ }^{38}$ Ralph Barnes Grindrod, Malvern: past and present, Malvern, 1865, pp. 14-15, 106; J. Webster, Malvern and its environs, Malvern, 1858, p. 70.

39 Joseph Buckley, Matlock Bank, (Derbyshire) as it was, and is, London, 1866, pp. 12-18, 22, 61; idem, Recollections of the late John Smedley, Manchester, 1888. The essay of Kelvin Rees, 'Water as a commodity: hydropathy in Matlock', in R. Cooter (ed.), Studies in the history of alternative medicine, London, Macmillan, 1988, pp. 28-45, did not come to my attention in time for me to incorporate his stimulating account of John Smedley's social context into this study.
} 